\title{
Front Matter: Volume 7117
}

, "Front Matter: Volume 7117," Proc. SPIE 7117, Millimetre Wave and Terahertz Sensors and Technology, 711701 (22 October 2008); doi: 10.1117/12.817095

SPIE. Event: SPIE Security + Defence, 2008, Cardiff, Wales, United Kingdom 


\section{PROCEEDINGS OF SPIE}

\section{Millimetre Wave and Terahertz Sensors and Technology}

Keith A. Krapels

Neil A. Salmon

Editors

17-18 September 2008

Cardiff, Wales, United Kingdom

Sponsored by

SPIE Europe

Cooperating Organisations

EMRSDTC-The Electro-Magnetic Remote Sensing Defence Technology Centre

(United Kingdom)

FOl-Swedish Defence Research Agency (Sweden)

Institute of Photonics (United Kingdom)

Luminex Corporation (USA)

Technium OpTIC (United Kingdom)

WOF-Welsh Opto-electronics Forum (United Kingdom)

Published by

SPIE

Volume 7117 
The papers included in this volume were part of the technical conference cited on the cover and title page. Papers were selected and subject to review by the editors and conference program committee. Some conference presentations may not be available for publication. The papers published in these proceedings reflect the work and thoughts of the authors and are published herein as submitted. The publisher is not responsible for the validity of the information or for any outcomes resulting from reliance thereon.

Please use the following format to cite material from this book:

Author(s), "Title of Paper," in Millimetre Wave and Terahertz Sensors and Technology, edited by Keith A. Krapels, Neil A. Salmon, Proceedings of SPIE Vol. 7117 (SPIE, Bellingham, WA, 2008) Article CID Number.

ISSN 0277-786X

ISBN 9780819473493

Published by

SPIE

P.O. Box 10, Bellingham, Washington 98227-0010 USA

Telephone +1 3606763290 (Pacific Time) · Fax +1 3606471445

SPIE.org

Copyright (C) 2008, Society of Photo-Optical Instrumentation Engineers

Copying of material in this book for internal or personal use, or for the internal or personal use of specific clients, beyond the fair use provisions granted by the U.S. Copyright Law is authorized by SPIE subject to payment of copying fees. The Transactional Reporting Service base fee for this volume is $\$ 18.00$ per article (or portion thereof), which should be paid directly to the Copyright Clearance Center (CCC), 222 Rosewood Drive, Danvers, MA 01923. Payment may also be made electronically through CCC Online at copyright.com. Other copying for republication, resale, advertising or promotion, or any form of systematic or multiple reproduction of any material in this book is prohibited except with permission in writing from the publisher. The CCC fee code is 0277-786X/08/\$18.00.

Printed in the United States of America.

Publication of record for individual papers is online in the SPIE Digital Library.

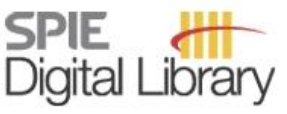

SPIEDigitalLibrary.org

Paper Numbering: Proceedings of SPIE follow an e-First publication model, with papers published first online and then in print and on CD-ROM. Papers are published as they are submitted and meet publication criteria. A unique, consistent, permanent citation identifier (CID) number is assigned to each article at the time of the first publication. Utilization of CIDs allows articles to be fully citable as soon they are published online, and connects the same identifier to all online, print, and electronic versions of the publication. SPIE uses a six-digit CID article numbering system in which:

- The first four digits correspond to the SPIE volume number.

- The last two digits indicate publication order within the volume using a Base 36 numbering system employing both numerals and letters. These two-number sets start with 00, 01, 02, 03, 04, 05 , $06,07,08,09,0 A, O B \ldots$. OZ, followed by 10-1Z, 20-2Z, etc.

The CID number appears on each page of the manuscript. The complete citation is used on the first page, and an abbreviated version on subsequent pages. Numbers in the index correspond to the last two digits of the six-digit CID number. 


\section{Contents}

vii Conference Committee

\section{SESSION 1 SYSTEMS I}

711702 The history of passive millimetre-wave imaging at QinetiQ [7117-01]

R. Appleby, QinetiQ (United Kingdom)

$71170494 \mathrm{GHz}$ FMCW cloud radar [7117-03]

P. G. Huggard, M. L. Oldfield, B. P. Moyna, B. N. Ellison, D. N. Matheson, Science and Technology Facilities Council (United Kingdom); A. J. Bennett, C. Gaffard, T. Oakley, J. Nash, UK Met Office (United Kingdom)

711705 Real-time terahertz imaging of nonmetallic objects for security screening and anticounterfeiting applications [7117-04]

B. N. Behnken, G. Karunasiri, Naval Postgraduate School (United States)

\section{SESSION 2 SYSTEMS II}

711706 Analytical model and optical design of distributed aperture system for millimeter-wave imaging [7117-12]

C. Chen, Univ. of Delaware (United States); C. A. Schuetz, R. D. Martin, Phase Sensitive Innovations, Inc. (United States); J. Samluk, E. L. Stein, Jr., D. G. MacKrides, Univ. of Delaware (United States); M. Mirotznik, The Catholic Univ. of America (United States); D. W. Prather, Univ. of Delaware (United States)

711707 A multifaceted active swept millimetre-wave approach to the detection of concealed weapons [7117-06]

D. A. Andrews, N. Bowring, N. D. Rezgui, M. Southgate, Manchester Metropolitan Univ. (United Kingdom); E. Guest, Leeds Metropolitan University (United Kingdom); S. Harmer, A. Atiah, Manchester Metropolitan Univ. (United Kingdom)

711708 Millimetre wave sensors for non-invasive inspection of people and luggage [7117-07] D. Nuessler, H. Essen, M. Haegelen, S. Stanko, G. Briese, FGAN—Research Institute for High Frequency Physics and Radar Techniques (Germany) 
711709 Compact and light-weight digital beam-forming passive millimetre imagers [7117-08] N. A. Salmon, J. Beale, S. Hayward, QinetiQ (United Kingdom); P. Hall, Birmingham Univ. (United Kingdom); R. Macpherson, ALPS UK Electric (United Kingdom); R. Metcalfe, Circuit Consultants Ltd. UK (United Kingdom); A. Harvey, Heriot Watt Univ. (United Kingdom)

$71170 \mathrm{~A}$ Study of responsiveness of near-field terahertz imaging probes [7117-09]

M. Berta, F. Kadlec, Institute of Physics (Czech Republic)

\section{SESSION 3 SIGNATURES I}

$71170 \mathrm{C}$ Study of passive MMW personnel imaging with respect to suspicious and common concealed objects for security applications [7117-05]

S. Dill, M. Peichl, H. SüB, DLR, Microwaves and Radar Institute (Germany)

7117 OD A novel low-cost alternative to THz for security and defence applications [71 17-32]

G. G. Diamond, D. A. Hutchins, P. Pallav, R. J. Green, Univ. of Warwick (United Kingdom)

7117 OE Passive millimetre wave imaging for ballistic missile launch detection [7117-14]

C. J. Higgins, N. A. Salmon, QinetiQ (United Kingdom)

7117 OF Material scanner in the submillimeter-wave region: configuration and signal processing [7117-15]

C. Krebs, RheinAhrCampus (Germany); S. Schneider, A. Hommes, D. Nüßler, Research Institute for High Frequency Physics and Radar Techniques (Germany)

$71170 \mathrm{O}$ On 3D radar data visualization and merging with camera images [7117-16]

J. Kjellgren, Swedish Defence Research Agency (Sweden)

$7117 \mathrm{OH}$ Development of a $210 \mathrm{GHz}$ near-field measurement radar system based on an antennaintegrated MMIC receiver front-end and an ultra-compact HBV transmitter source module [7117-17]

J. A. M. Svedin, J. Kjellgren, S. Rudner, Swedish Defence Research Agency (Sweden);

G. Thordarsson, Saab Microwave Systems (Sweden); S. E. Gunnarsson, N. Wadefalk,

S. Cherednichenko, I. Angelov, H. Zirath, J. Stake, T. Bryllert, J. Vukusic, Chalmers Univ. of Technology (Sweden)

\section{SESSION 4 SIGNATURES II}

71170 Remote respiration and heart rate monitoring with millimeter-wave/terahertz radars [7117-18]

D. T. Petkie, E. Bryan, C. Benton, C. Phelps, J. Yoakum, M. Rogers, A. Reed, Wright State Univ. (United States)

$71170 \mathrm{~J}$ Detection of concealed explosives at stand-off distances using wide band swept millimetre waves [7117-19]

D. A. Andrews, N. D. Rezgui, S. E. Smith, N. Bowring, M. Southgate, J. G. Baker, Manchester Metropolitan Univ. (United Kingdom) 
7117 OK A microwave measurement system for metallic object detection using swept-frequency radar [7117-20]

Y. Li, G. Y. Tian, Newcastle Univ. (United Kingdom); N. Bowring, N. Rezgui, Manchester

Metropolitan Univ. (United Kingdom)

$7117 \mathrm{OL}$ Through-the-wall high-resolution imaging of a human and experimental characterization of the transmission of wall materials [7117-21]

S. Nilsson, A. Jänis, M. Gustafsson, J. Kjellgren, A. Sume, Swedish Defence Research Agency (Sweden)

$71170 \mathrm{M} \quad$ Phong-like lighting for MMW radar simulation [7117-22]

N. Peinecke, H.-U. Doehler, B. R. Korn, German Aerospace Ctr., DLR (Germany)

\section{SESSION 5 COMPONENT TECHNOLOGY I}

$71170 \mathrm{~N} \quad$ Trends in Schottky receiver technology for the terahertz region [7117-23]

B. Alderman, H. Sanghera, B. Moyna, M. Oldfield, D. Matheson, STFC-Rutherford Appleton Lab. (United Kingdom)

711700 Enabling compact MMIC-based frontends for millimeter-wave imaging radar and radiometry at 94 and $210 \mathrm{GHz}$ [7117-24]

I. Kallfass, A. Tessmann, A. Leuther, M. Kuri, M. Riessle, M. Zink, H. Massler, M. Schlechtweg,

O. Ambacher, Fraunhofer Institute for Applied Solid-State Physics (Germany)

$7117 \mathrm{OP} \quad$ Superconducting and semiconducting YBCO thin film bolometer investigations for future THz imaging arrays [7117-25]

V. S. Jagtap, A. F. Dégardin, M. Longhin, M. Aurino, A. J. Kreisler, SUPELEC/LGEP, CNRS/UMR 8507, UPMC Univ Paris 06, Univ Paris Sud 11 (France)

$7117 \mathrm{OQ} \quad$ Modelling THz antennas for cooled superconducting and uncooled semiconducting bolometric pixels [7117-26]

I. Türer, A. Scheuring, X. Gaztelu, SUPELEC/LGEP, CNRS/UMR 8507, UPMC Univ Paris 06, Univ Paris Sud 11 (France); N. Ribière-Tharaud, SUPELEC/DRE (France); A. F. Dégardin,

A. J. Kreisler, SUPELEC/LGEP, CNRS/UMR 8507, UPMC Univ Paris 06, Univ Paris Sud 11 (France)

$7117 \mathrm{OR} \quad$ Novel $\mathrm{mm}$-wave and THz radiation active imaging system based on glow discharge detector (GDD) pixel [7117-27]

N. S. Kopeika, Ben-Gurion Univ. of the Negev (Israel); A. Abramovich, Ariel Univ. Ctr. of Samaria (Israel); D. Rozban, Ben-Gurion Univ. of the Negev (Israel)

\section{SESSION 6 COMPONENT TECHNOLOGY II}

7117 OS Coherent superposition of terahertz beams [7117-28]

S. Preu, S. Malzer, G. H. Döhler, L. J. Wang, Univ. of Erlangen-Nürnberg (Germany)

7117 OT $94 \mathrm{GHz}$ millimeter-wave imaging system implementing optical upconversion [7117-29] J. P. Samluk, C. A. Schuetz, R. D. Martin, E. L. Stein, Jr., D. G. Mackrides, C. Chen, P. Yao, R. Shireen, J. Macario, D. W. Prather, Univ. of Delaware (United States) 
7117 OV Characteristic of 2D triangular lattice of photonic crystals for microwave and photonic devices [7117-31]

K. L. Low, M. Z. Mat Jafri, S. A. Khan, Univ. Sains Malaysia (Malaysia); A. J. Bin Yusof, Intel Microelectronics (United States)

Author Index 


\title{
Conference Committee
}

\author{
Symposium Chair \\ David H. Titterton, Defence Science and Technology Laboratory \\ (United Kingdom) \\ Conference Chairs
}

Keith A. Krapels, Night Vision and Electronic Sensors Directorate (United States)

Neil A. Salmon, QinetiQ Ltd. (United Kingdom)

Program Committee

Amir Abromovich, The College of Judea and Samaria (Israel)

Markus Peichl, DLR Standort Oberpfaffenhofen (Germany)

Douglas T. Petkie, Wright State University (United States)

Christopher A. Schuetz, University of Delaware (United States)

Steve Gunderson, Naval Facilities Engineering Service Center (United States)

\section{Session Chairs}

1 Systems I

Keith A. Krapels, Night Vision and Electronic Sensors Directorate (United States)

Neil A. Salmon, QinetiQ Ltd. (United Kingdom)

Steve Gunderson, Naval Facilities Engineering Service Center (United States)

2 Systems II

Markus Peichl, DLR Standort Oberpfaffenhofen (Germany)

Christopher A. Schuetz, University of Delaware (United States)

Amir Abromovich, The College of Judea and Samaria (Israel)

3 Signatures I

Douglas T. Petkie, Wright State University (United States)

Neil A. Salmon, QinetiQ Ltd. (United Kingdom)

Steve Gunderson, Naval Facilities Engineering Service Center (United States) 
4 Signatures II

Keith A. Krapels, Night Vision and Electronic Sensors Directorate (United States)

Markus Peichl, DLR Standort Oberpfaffenhofen (Germany)

Christopher A. Schuetz, University of Delaware (United States)

5 Component Technology I

Steve Gunderson, Naval Facilities Engineering Service Center (United States)

Neil A. Salmon, QinetiQ Ltd. (United Kingdom)

Amir Abromovich, The College of Judea and Samaria (Israel)

6 Component Technology II

Keith A. Krapels, Night Vision and electronic Sensors Directorate (United States)

Douglas T. Petkie, Wright State University (United States)

Markus Peichl, DLR Standort Oberpfaffenhofen (Germany) 